\title{
Fontan Fenestration and the Role of the Covered Stent
}

\author{
Satinder Sandhu ${ }^{1}$ and Fahad Alfares ${ }^{1}$ \\ ${ }^{1}$ University of Miami Miller School of Medicine
}

July 28, 2021

\begin{abstract}
Key Points : * Interventional therapies directed at fenestration closure in the Fontan patient must rely on good hemodynamic data * The Large Optimus-CVSTM stent is an additional armamentarium for fenestration closure however, longer term follow up is needed $*$ Multi institutional studies defining the long-term benefits of fenestration closure and outlining fenestration management guidelines may help improve the long-term morbidity and mortality in this group of patients.
\end{abstract}

Title: Fontan Fenestration and the Role of the Covered Stent

Authors : Fahad Alfares, Satinder K Sandhu

Affiliation : Division of Pediatric Cardiology, Department of Pediatrics, University of Miami, Miller School of Medicine

Funding: There was no source of funding.

Disclosure: The authors state that there was no relationship with any industry and there was no conflict of interest.

\section{Corresponding Author Information:}

Dr. Satinder Sandhu MD

Professor of Pediatrics

Director, Pediatric Cardiac Cath Laboratory

Director, Adult Congenital Heart Disease

1611 NW 12th Avenue, NW Room109

Miami, Florida, 33136

Phone: 305-585-6683

Fax: 305-324-6012

Email: ssandhu3@med.miami.edu

Acknowledgements : The authors have no acknowledgments to mention

Key Points :

- Interventional therapies directed at fenestration closure in the Fontan patient must rely on good hemodynamic data

- The Large Optimus-CVS ${ }^{\mathrm{TM}}$ stent is an additional armamentarium for fenestration closure however, longer term follow up is needed 
- Multi institutional studies defining the long-term benefits of fenestration closure and outlining fenestration management guidelines may help improve the long-term morbidity and mortality in this group of patients.

Fontan and Baudet (1) in 1971 first reported the repair of tricuspid atresia with a surgical procedure now known as "Fontan repair". The Fontan repair has undergone multiple modifications (2-8) to optimize the physiologic and anatomic factors that play a vital role in the Fontan circulation. In 1988 Laks et al (7) described the creation of an adjustable fenestration which in the post-operative period allowed controlled right to left shunting allowing for improved cardiac output and decreasing the incidence of post-operative pleural effusions. The benefit of the fenestration comes at the cost of a lower systemic arterial saturation and the increased risk of stroke. Closure of the fenestration spontaneously or intentionally improves the arterial saturation and may reduce the risk of thromboembolic events (9).

Haddad et al present a case series of three patients with total cavo-pulmonary connection with an extracardiac interposition Gore-Tex graft (W.L. Gore \& Associates, Inc., Flagstaff, AZ, USA) of 16 or 18mm with a 5-mm punch-hole-type fenestration. After hemodynamic evaluation the patients underwent fenestration closure with a $43 \mathrm{~mm} /$ Large Optimus-CVS ${ }^{\mathrm{TM}}$ stent crimped over a Altosa-XL ${ }^{\mathrm{TM}} \mathrm{PTA}$ balloon catheter (AndraTec GmbH, Koblenz, Germany) and implanted through a $10 \mathrm{Fr}$ delivery sheath. The stent was placed across the fenestration in the extra cardiac Gor-tex graft. At follow up immediately and at one month there was no residual shunt across the fenestration. The Optimus-CVS ${ }^{\mathrm{TM}}$ is a balloon-expandable stent with a HD-Cobalt-Chromium-MP35N alloy frame that is flexible because of the hybrid cell design and has excellent radial strength. The PTFE-cover on the stent has a unique end-free sealing design which minimizes the risk of overhanging. The Altosa-XL ${ }^{\mathrm{TM}} \mathrm{PTA}$ balloon catheter is a high pressure low profile balloon catheter which may allow for a smaller sheath size to deliver the stent making it particularly attractive in children.

There is currently no single ideal device for fenestration closure and to some extent the selection of the device is dictated by the size and location of the fenestration and operator preference. Several devices have been used in fenestration closure including occluder devices and covered stents (10-12). The occluder devices and the stents have their merits and drawbacks. Covered stents are effective in closing fenestrations with good mid-term results (11). The immediate results for fenestration closure with the Large Optimus-CVS ${ }^{\mathrm{TM}_{\text {stent }}}$ is promising. Long term follow-up in a larger cohort of patients is needed to better assess the efficacy and safety of this stent in closing Fontan fenestrations. Customized covered biodegradable stents may prove a good alternative to the traditional stents.

The overwhelming unknown factor remains the selection of patients who would benefit long term from fenestration closure. Hijazi et al (13) in an elegant study demonstrated that immediately following balloon occlusion of the fenestration there was an immediate increase in aortic saturation with decreased cardiac output. The increase in aortic saturation did not fully compensate for the decrease in cardiac output resulting in a decrease in systemic oxygen delivery and an increase in oxygen extraction in the vast majority of patients. In addition, short term follow-up studies following fenestration closure (14-15) demonstrate an increase in the arterial oxygen saturation but not greater event free survival. Multi institutional studies defining the long-term benefits of fenestration closure and outlining fenestration management guidelines may help improve the long-term morbidity and mortality in this group of patients.

\section{REFERENCES:}

1. Fontan F, Baudet E: Surgical repair of tricuspid atresia. Thorax 1971;26:240-248

2. Rychik J, Atz AM, Celermajer DS, Deal BJ, Gatzoulis MA, Gewillig MH, Hsia TY, Hsu DT, Kovacs $\mathrm{AH}$, McCrindle BW, Newburger JW, Pike NA, Rodefeld M, Rosenthal DN, Schumacher KR, Marino BS, Stout K, Veldtman G, Younoszai AK, d'Udekem Y: American Heart Association Council on Cardiovascular Disease in the Young and Council on Cardiovascular and Stroke Nursing. Evaluation and Management of the Child and Adult With Fontan Circulation: A Scientific Statement From the American Heart Association. Circulation. 2019; 140:e234-e284

3. de Vivie E-R, Rupprath G: Long-term results after Fontan procedure and its modification. J Thorac 
Cardiovasc Surg 1986; 91:690-697

4. Gale AW, Danielson GK, McGoon DC, Mair DD: Modified Fontan operation for univentricular heart and complicated congenital lesions. J Thorac Cardiovas Surg 1979; 78:831-838.

5. Humes RA, Mair DD, Porter CJ: Results of the modified Fontan operation in adults. Am J Cariol 1988; 61:602-604

6. Bartmus DA, Driscoll DJ, Offord KP, Humes RA, Mair DD, Schaff HV, Puga FJ, Danielson GK: The modified Fontan operation for children less than 4 years old. J Am Coll Cardiol 1990; 15:429-435

7. Laks H, Haas GS, Pearl JM, Sadeghi AM, George B, Santulli TV, Williams RG: The use of an adjustable intra-atrial communication in patients undergoing the Fontan and definitive heart procedures. Circulation 1988; 78(II): 357

8. Bridges ND, Lock JE, Castaneda AR: Baffle fenestration with subsequent transcatheter closure: Modification of the Fontan operation for patients at increased risk. Circulation 1990;82: 1681-1689

9. Gorla SR, Jhingoeri NK, Chakrkaborty A, Raja KR, Garg A, Sandh S, Rosenkranz ER, Swaminathan S. Incidence and factors influencing the spontaneous closure of Fontan fenestration. Congenit Heart Dis. 2018;12(5):776-781. Webb MK, Hunter LE, Kremer TR, Huddleston CB, Fiore AC, Danon S. Extracardiac Fontan Fenestration Device Closure with Amplatzer Vascular Plug II and Septal Occluder: Procedure Results and Medium-Term Follow-Up. Pediatr Cardiol. 2020; 41(4):703-708.

10. Kim SH, Kang IS, Huh J, Lee HJ, Yang JH, Jun TG. Transcatheter closure of fenestration with detachable coils after the Fontan operation. J Korean Med Sci. 2006 Oct;21(5):859-6

11. Malekzadeh-Milani S, Ladouceur M, Bajolle F, Bonnet D, Boudjemline Y. Closure of Fontan fenestration with the use of covered stents: short- and mid-term results in a cohort of 50 patients. Cardiol Young. 201; 25(5):868-73.

12. Jeong SI, Huh J, Lee HJ, Yang JH, Jun TG, Kang IS. Closure of conduit fenestration after extracardiac Fontan procedure using Amplatzer vascular plug: comparison with detachable coil. Pediatr Cardiol. 2010; 31(1):44-9.

13. Ziyad M. Hijazi, MD; John T. Fahey, MD; Charles S. Kleinman, MD; Gary S. Kopf, MD; and William E. Hellenbrand, MD: Hemodynamic Evaluation Before and After Closure of Fenestrated Fontan. An Acute Study of Changes in Oxygen Delivery. Circulation Vol 86, No 1 July 1992:196-202

14. Imielski BR, Woods RK, Mussatto KA, Cao Y, Simpson PM, Tweddell JS. Fontan fenestration closure and event-free survival. J Thorac Cardiovasc Surg 2013; 145(1):183-187

15. Pihkala J, Yazaki S, Mehta R, Lee KJ, Chaturvedi R, McCrindle BW, Arsdell GV, Benson LN. Feasibility and clinical impact of transcatheter closure of interatrial communications after a fenestrated Fontan procedure: medium-term outcomes. Catheter Cardiovasc Interv.2007; 69(7):1007-1014. 